\title{
Sustainable Earth begins its journey
}

CrossMark

\section{Peter Newman}

'Earth Day' was first celebrated in 1970 and gave voice to many concerns about the global environment. Scientists played a major role in drawing attention to our impact on the planet and millions marched in response. Across the world nations, cities, businesses and communities began to address these environmental issues.

The 1970's and 80's saw the rise of environmental science, EPAs, environmental policy and environmental assessment with the worst pollution of air, water and land being addressed. But deeper issues about our consumption of energy, materials, food and forests began to surface and serious questions were asked about global limits and the pursuit of single-minded economic development. Should we stop economic growth? What about the 1 billion people in extreme poverty - are they going to suffer if we focus on the environment?

The UN's World Commission on Environment and Development in 1987 resolved this issue in theory by creating the idea of 'sustainable development'. This suggested that we could grow economically but that it should help the environment, not destroy it. For the next 20 years scientists, communities and policy makers have been trying to work toward this. Sustainability research has now become one of the fastest growing scientific fields today.

So, why do we need a new journal, Sustainable Earth? In 2000 the world agreed to the Millenium Development Goals which were highly successful in that global extreme poverty was reduced from around $40 \%$ to $15 \%$ and many global social goals improved dramatically; but the global environmental goals deteriorated especially on climate change and biodiversity. So, in 2016 the nations of the world signed up to the Sustainable Development Goals (SDGs) [1] and the Paris Agreement on Climate Change. Now we must make a huge global shift toward a sustainable earth - this is the world's main long term priority.

To do this we need the science of sustainability to reach not only policy makers but society itself. We must communicate the gravity of our global environmental situation clearly to people in the community as well as policy makers. This is why our website says the journal

Correspondence: P.Newman@curtin.edu.au

Curtin University, Perth, Australia is about 'Science, Policy and Society'. Not every paper will be relevant to all audiences, but in this journal we hope to bring the science of a sustainable earth into one or more of the arenas that relate to society or to policy.

The first three articles in Sustainable Earth begin to set out this goal:

1. Kate Meyer and Peter Newman, "The Planetary Accounting Framework: A novel, quota based approach to understanding the impacts of any scale of human activity in the context of the Planetary Boundaries".[2] This paper addresses the grand scale of the environmental challenges facing the earth which have been addressed by the scientists involved in creating the Planetary Boundaries (PBs). The issues driving this paper are how to translate the Planetary Boundaries into something that can be used by communities and policy makers. The paper sets out to bring the PBs into a single framework and then seeks to make them scalable based on a per capita figure. The paper finishes by suggesting how it may be possible to now create a series of programs that enable individuals, cities, businesses and nations to do the kind of auditing related to impact that so far is really only done over global carbon emissions. This paper also features a video created by the Research Square, to demonstrate the ideas behind the paper.

2. Fortunate Machingura, Admire Mutsa Nyamwanza, David Hulme, and Elizabeth Stuart, "Climate information services, Integrated knowledge systems and the 2030 Agenda for Sustainable Development". [3] The topic of this paper begins to address the issues outlined above on the brief history of sustainability. We now have global agreements to work toward the 17 Sustainable Development Goals (SDG's) and the Paris Agreement on Climate Change simultaneously. Even the simplest reading of this task will show that we are not equipped to integrate these vastly different goals and completely reshape the global economy around new clean energy sources at the same time. The authors of this paper are making a 
start by showing how critical it is to begin integrating the information systems and knowledge services around these multiple goals, so they can communicate with both policy makers and the global community. They suggest that a new kind of 'inclusive knowledge system' needs to be created that has the reliability of science but can communicate at multiple levels, such as weather forecasts. This paper addresses a similar challenge to the Planetary Boundaries paper in its scope, but suggests that the climate and weather service focus demonstrates how to provide a science-based set of evidence, which may enable similar evidence sets to be built around all of the SDG's.

3. Robert McDonald, Timothy Beatley, and Thomas Elmqvist, "The green soul of the concrete jungle: The urban century, the urban psychological penalty, and the role of nature".[4] This paper starts a theme that is likely to be very common in Sustainable Earth - how do we make cities more sensitive to the world of nature? The authors set out how humans have now made cities our main habitat and they vary in density and scale across the globe. There is extensive literature on how much density and scale of cities impacts on human health or whether the variations are mostly due to wealth, social and political factors or cultural factors. Whatever it is that causes health to vary there is little doubt - according to this paper - that integrating nature into our cities has many health benefits, especially for mental health. The best cities at bringing nature into their fabric, like Singapore, are examined to determine what policy makers can do to help. This is called Biophilic Urbanism, a topic we will hear a great deal more about in the future.

The last two of these papers are associated with article collections, which group papers around a common theme within the scope of Sustainable Earth. These article collections will attract a range of papers in order to assemble a knowledge base that advances research in each theme. Some of these article collections are already inviting submissions, including:

1. Accelerating Climate Change Mitigation.

2. Food and Sustainable Earth.

3. Young Lives for a Sustainable Earth.

4. Biophilic Urbanism.

Other important and emerging topics will be addressed in the journal in future article collections, on topics such as plastic waste, predictive analytics and big data, smart cities, inclusion and affordable access, motivation, governance and consensus, and water, all within the context of a Sustainable Earth.

As explained above, Sustainable Earth serves not only the scientific community but seeks to directly relate to the general public and seeks opportunities to directly engage in practical sustainability initiatives. As a first step, the journal is supporting the Earth Day Network's Canopy Project, which is seeking to plant 7.8 billion trees (one for each person on the planet) by 2020. Sustainable Earth will donate one tree for every peer review report in the journal.

Please join us in reading, contributing to, and reviewing for Sustainable Earth.

Authors' contributions

The author read and approved the final manuscript.

Competing interests

The Editor-in-Chief of the journal, Peter Newman, is the author of this paper. As an editorial, this is an opinion piece and was therefore not peer reviewed. The author declares that he does not have any competing interests.

\section{Publisher's Note}

Springer Nature remains neutral with regard to jurisdictional claims in published maps and institutional affiliations.

Received: 8 September 2018 Accepted: 12 September 2018 Published online: 25 October 2018

\section{References}

1. Sustainable Development Knowledge Platform. Sustainable Development Goals. https://sustainabledevelopment.un.org/sdgs. Accessed 10 Sept 2018

2. Meyer K, Newman P. The Planetary Accounting Framework: A novel, quota based approach to understanding the impacts of any scale of human activity in the context of the Planetary Boundaries. Sustain Earth. 2018;1:X. https://doi.org/10.1186/s42055-018-0004-3.

3. Machingura F, Nyamwanza AM, Hulme D, Stuart E. Climate information services, Integrated knowledge systems and the 2030 Agenda for sustainable development. Sustain Earth. 2018;1:X. https://doi.org/10.1186/ s42055-018-0003-4.

4. Mcdonald RI, Beatley T, Elmqvist T. The green soul of the concrete jungle: The urban century, the urban psychological penalty, and the role of nature. Sustain Earth. 2018;1:X. https://doi.org/10.1186/s42055-018-0002-5.

Ready to submit your research? Choose BMC and benefit from:

- fast, convenient online submission

- thorough peer review by experienced researchers in your field

- rapid publication on acceptance

- support for research data, including large and complex data types

- gold Open Access which fosters wider collaboration and increased citations

- maximum visibility for your research: over $100 \mathrm{M}$ website views per year

At BMC, research is always in progress.

Learn more biomedcentral.com/submissions 